\title{
1988 Essex Scholarships
}

The Canadian Political Science Association hopes again to receive a grant from the Social Sciences and Humanities Research Council of Canada to permit three Canadian members to attend the Summer School in Social Science Data Analysis and Collection held each year at The University of Essex, Colchester, England. The course is sponsored by The Department of Government at Essex and by the European Consortium for Political Research. It is very highly regarded and is attended by Western Europeans and some North Americans.

The Association offers three scholarships, of slightly in excess of $\$ 2,000$ each, to defray the cost of travel, fees and accommodation for the obligatory four-week stay. The programme takes place in July and August of each year.

The Selection Committee requires evidence of a commitment to the political science profession and invites applications from both faculty and graduate students.

We invite enquiries and will respond with the terms of reference of the programme as well as information on how to make a formal application.

Please write, by December 31, 1987, to The Secretary-Treasurer, The Canadian Political Science Association, 12 Henderson Avenue, The University of Ottawa, Ottawa, Canada K1N 6 N5.

\section{Bourses d'Études 1988 à The University of Essex}

L'Association canadienne de science politique espère recevoir encore une subvention du Conseil de recherches en sciences humaines du Canada pour permettre à trois de ses membres canadiens de participer au séminaire d'été de The University of Essex à Colchester, Angleterre (The Essex Summer School in Social Science Data Analysis and Collection). Ce séminaire est co-patronné par The Department of Government à The University of Essex et « The European Consortium for Political Research ». Participent à ce seminaire de haut niveau des chercheurs venus d'Europe occidentale et d'Amérique du Nord.

L'Association offre trois bourses d'environ $2000 \$$ destinés à defrayer le coût de voyage, les frais d'inscription, et le logement pour un séjour obligatoire de quatre semaines. Le séminaire a lieu chaque année en juillet-août.

Les candidat(e)s devront faire preuve d'un intérêt certain pour la science politique et peuvent être ou des professeurs ou des étudiant(e)s de troisième ou de deuxième cycles.

Pour plus de renseignements concernant ce programme, ainsi que les critères de sélection, veuillez écrire avant le 31 décembre 1987, au Secrétaire-trésorier, Association canadienne de science politique, 12, rue Henderson, Université d'Ottawa, Ottawa, Canada K1N 6N5. 